\title{
UNA NEGOCIACIÓN CLAVE PARA LA PAZ: LA MISIÓN DEL MARQUÉS DE MONTELEÓN EN LONDRES (1712-1713)
}

\author{
Manuel Alejandro Castellano García \\ Universitat Pompeu Fabra
}

\begin{abstract}
RESUMEN. En este artículo analizamos en profundidad la misión diplomática del marqués de Monteleón, enviado a Londres en las postrimerías de la Guerra de Sucesión española para completar el tratado de paz preliminar entre España y Gran Bretaña. Nos acercaremos a las tácticas empleadas por los negociadores de ambas potencias sin perder de vista la influencia francesa y de la misión diplomática que llevaba a cabo Lord Lexington en Madrid. Además, siendo esta negociación bilateral la primera vez que Felipe $V$ pudo negociar con voz propia, nos permite presentar los objetivos y ambiciones del monarca español. Buscamos así proporcionar una visión global sobre una compleja negociación que definió de manera definitiva los acuerdos entre ambas potencias, posteriormente ratificados en Utrecht.
\end{abstract}

Palabras clave: Diplomacia, Guerra de Sucesión española, Monteleón, Relaciones internacionales, Paz de Utrecht.

ABSTRACT. In this paper, we examine in depth the diplomatic mission of the Marquis of
Monteleón, sent to London in the aftermath of the war of the Spanish Succession to complete
the preliminary peace between Spain and Great Britain. We will approach the tactics used
by the negotiators of both potencies without losing sight of the French influence, and the
diplomatic mission carried out by Lord Lexington in Madrid. Furthermore, being this bilateral
negotiation the first time that Philip V could negotiate with his own voice, allows us to present
the objectives and ambitions of the Spanish monarch. In this way, we seek to provide a global
vision of a complex negotiation that conclusively defined the agreements between both powers
subsequently ratified in Utrecht. Keywords: Diplomacy, War of the Spanish Succession, Monteleón, International relations, Peace of Utrecht.

Recibido: 2-1-2020 • Aceptado: 16-6-2020 • manuelcastellanogarcia@gmail.com 
EN Utrecht, salvo algunas cuestiones puntuales, los plenipotenciarios de Felipe V prácticamente se limitaron a rubricar acuerdos previamente alcanzados lejos de allí. Su negociación se alejó de lo sucedido en dicho congreso, confirmando como el proceso que permite concluir una guerra suele moverse por caminos alejados de la oficialidad de las conferencias generales de paz. Así, si bien los puntos básicos que debía conceder la monarquía hispánica a Gran Bretaña fueron ajustados de manera bilateral y secreta entre Londres y Versalles, la paz se concluyó en una doble negociación hispano-británica realizada por Lord Lexington en Madrid y el marqués de Monteleón en Londres. Esta permitió a Felipe V negociar por vez primera sin la intermediación francesa, a quienes los británicos habían reconocido hasta entonces como únicos interlocutores válidos del bando borbónico.

Por ello, y habiendo sido recientemente estudiada la embajada de Lord Lexington pretendemos profundizar en la misión del marqués de Monteleón ${ }^{1}$. El estudio de las distintas estrategias empleadas y sus modificaciones según avanzaba la negociación así como de la correspondencia cruzada entre las cortes y diplomáticos, amigos y enemigos, de las cortes de Londres, Madrid y París nos permitirán una mayor comprensión de una negociación que, modificando incluso aspectos previamente acordados por Lexington, fijó definitivamente la paz hispano-británica.

\section{Llegada de Monteleón a Londres y primera toma de contacto}

La supeditación a la diplomacia francesa durante las negociaciones para finalizar la Guerra de Sucesión española supuso un trago amargo para Felipe V. Además de verse obligado a otorgar poderes a Luis XIV para negociar en su nombre y renunciar a sus derechos al trono francés, debió asumir que sus plenipotenciarios no serían admitidos en Utrecht hasta que se hubiese acordado lo referente a la monarquía hispánica.

Para intentar desagraviarle y no enrarecer en demasía sus relaciones Luis XIV ofreció que sus plenipotenciarios —el marqués de Monteleón, el duque de Osuna y el conde de Bergeyck - esperasen en París a ser admitidos en Utrecht, comprometiéndose a mediar para que fuese lo antes posible (Guillamón y Muñoz, 2008, pp. 181-182). La propuesta fue aceptada por el monarca, desconocedor de la falsedad de la prometida mediación: Torcy ya había confirmado a los británicos que la ausencia de los representantes de Felipe V en Utrecht no retrasaría unas negociaciones que comenzarían mucho antes de que llegasen a París $^{2}$.

Storrs, 2013, pp. 77-99.

Parke, 1798, vol.2, pp. 65-69, Torcy a Bolingbroke, 15-XII-1711. 
Llegados a París, los plenipotenciarios de Felipe V pronto comprendieron que estaban siendo entretenidos mientras otros decidían el destino de la monarquía hispánica. Aunque tratados acorde a lo que merecían los representantes de una potencia aliada Osuna no tardó en lamentar que no tenían oportunidad de realizar ninguna propuesta, y de hecho fueron mantenidos tan al margen que en muchas ocasiones debieron informarse a través de las gacetas de Francia y Holanda (Bély, 2011, p. 163).

Saber que se dirigía allí Henry St. John, vizconde de Bolingbroke, Secretary of State for the Northern Department y una de las principales personalidades del gobierno británico, aumentó su sensación de que la intención era «tratar y ajustar aquí todas las cosas pertenecientes a España sin dexarnos pasar al congreso hasta estar todo ajustado» ${ }^{3}$. Sus temores eran fundados, ya que el británico se negó a recibirles mientras duraron las conversaciones y Torcy únicamente les dijo que trataban asuntos comerciales, sin permitirles participar ni sugerir cuestión alguna (Fernández, 2011, pp. 121-122). Solo al concluir la negociación les comunicó los principales puntos acordados, el cese de armas y el envío de un embajador británico a Madrid para asistir a la renuncia de Felipe V. Todo ello enfureció a Osuna, que solicitó al monarca no consentir las cesiones acordadas y en septiembre llegaría a amenazar al poeta y diplomático británico Matthew Prior con romper la paz particular acordada (Guerrero, 2008, pp. 426-428), actuaciones que le ganaron la animadversión francesa y jugaron en su contra cuando llegó a Utrecht.

Pero este acuerdo y la llegada de Lexington a Madrid permitieron a Felipe V negociar por primera vez sin intermediación francesa y enviar un representante a Londres, algo que Luis XIV confiaba que ayudaría a reducir su malestar por no permitirse aún el paso de sus plenipotenciarios a Utrecht ${ }^{4}$. Pronto la misión en Londres adquirió gran importancia para los españoles. Las instrucciones de Lord Lexington le permitían únicamente confirmar y concretar lo pactado con Versalles, y aunque provocó una protesta inicial española argumentando que los franceses habían aceptado concesiones excesivas a cambio de una mejor paz para ellos ${ }^{5}$, también les esperanzó en poder mejorar en Londres las condiciones de los asuntos finalizados sin acuerdo en Madrid ${ }^{6}$.

El designado para acudir a Londres fue el marqués de Monteleón. Con amplio conocimiento sobre las cuestiones diplomáticas europeas y experto en el escenario italiano, mantenía excelentes relaciones con los más altos cortesanos de Felipe V y

Archivo Histórico Nacional (en adelante AHN), Estado, 3379-1, Osuna a Grimaldo, 10-II-1712.

Archive du Ministère des Affaires étrangères (en adelante AMAE), Correspondance Politique, Espagne, 215, f. 184, Torcy a Bonnac, 28-VIII-1712.

British Library (en adelante B.L.), Additional Manuscripts 6543A, f. 46, Lexington a Bolingbroke, 14-XI-1712.

6 AMAE, Correspondance Politique, Espagne, 217, ff. 48v-49, Torcy a Bonnac, 27-XI-1712. 
era muy bien visto en Versalles. Habiendo cumplido exitosamente otros encargos del monarca, lo que le sirvió para conseguir el marquesado y los nombramientos de consejero supernumerario del Consejo de Indias y gentilhombre de cámara del rey, su experiencia, don de gentes y la confianza que Madrid y París tenían en él lo convertían en un candidato idóneo (López-Cordón, 2020, pp. 140-141, 153-154). Como era de esperar, su elección también agradó a Torcy, que destacó sus buenos principios y convencimiento en la necesidad de concluir rápidamente la negociación ${ }^{7}$, recomendándolo a Bolingbroke:

j'espère que vous pourrez aplanir avec lui les difficultés que My Lord Lexington trouvera à traiter avec les Espagnols [...] Monteleon a de l'esprit \& de bonnes intentions $\&$ j'espère que vous trouverez qu'il facilitera tout ce qui aura pu faire quelque peine à Madrid ${ }^{8}$.

Sus instrucciones le encargaron solventar la cuestión religiosa en los territorios que iban a entregarse; mantener la negativa a cobijar o asistir a barcos infieles en Menorca y Gibraltar y que Gran Bretaña solo pudiera enajenarlas a España; ceder Sicilia únicamente a la línea masculina del duque de Saboya, revirtiendo en España de agotarse; negociar la devolución de Mallorca, Ibiza y Formentera; lograr el mantenimiento del derecho de pesca y secado de ballena y bacalao en Terranova; resolver la cuestión catalana y concretar la concesión de una soberanía a la princesa de los Ursinos ${ }^{9}$. No fue lo único a negociar, y siendo imposible acordarlo con Lexington también se le encargó llegar a un acuerdo en la pretendida rebaja del 15\% en los aranceles para los productos británicos ${ }^{10}$.

Consciente de la importancia de su misión Monteleón solicitó su pasaporte a principios de octubre ${ }^{11}$, mostrándose a finales del mismo mes impaciente por el perjuicio que suponía que se tratasen los intereses de la monarquía hispánica sin su presencia en Londres para defenderlos (Albareda, 2013, pp. 50-51). No dejó de intentar adelantar su partida, sugiriendo incluso que enviasen su pasaporte de forma que pudiera recogerlo en un punto intermedio de su viaje a Calais ${ }^{12}$ y anunciando el 12 de noviembre estar a punto de emprender el camino ${ }^{13}$. Pero los británicos solo autorizaron su viaje tras conocer que la renuncia de Felipe $\mathrm{V}$ al trono francés había sido realizada, debiendo

AMAE, Correspondance Politique, Espagne, 217, ff. 48v-49, Torcy a Bonnac, 27-XI-1712.

Parke, 1798, vol. 3, p. 216, Torcy a Bolingbroke, 10-XI-1712.

National Archives (en adelante N.A), State Papers, 105/269, sin numerar (en adelante s/n).

N.A, State Papers 94/79, s/n, Respuesta al memorial presentado por Lord Lexington.

N.A, State Papers 94/79, s/n, carta de Monteleón, 3-X-1712.

AMAE, Correspondance Politique, Espagne, 218, f. 569, Monteleón a Londres, 7- XI-1712.

AMAE, Correspondance Politique, Espagne, 218, f. 572, Monteleón a Londres, 12-XI-1712. 
esperar hasta que dos cartas de 25 de noviembre y 2 de diciembre confirmaron que se había ordenado facilitar su llegada a Londres (Guerrero, 2008, p. 481).

Recibido el visto bueno partió hacia Calais, donde llegó el 9 de diciembre ${ }^{14}$ para tomar una embarcación que lo dejó en Dover el día 11, arribando cinco días después a Londres. Pese a que su misión carecía de carácter oficial, entró con acompañamiento de honor y entre entusiastas vítores y vivas del pueblo reunido para la ocasión. También se le concedió una audiencia real y fue recibido fastuosamente por Dartmouth, Secretary of State for the Southern Department; Poulett, Lord Steward, y Bolingbroke ${ }^{15}$. Este último había preparado cuidadosamente su bienvenida contando con el beneplácito de Robert Harley, Lord High Treasurer y cabeza del gobierno británico, Dartmouth y la propia reina, sabedores de que satisfacer el ego de Monteleón aumentaría las posibilidades de un rápido éxito de la negociación ${ }^{16}$.

No era una cuestión menor para ellos, ya que el gabinete distaba de disfrutar de la fortaleza suficiente para asegurar su tranquilidad y necesitaba agilizar al máximo la conclusión del preliminar. Los tories se veían incapaces de capitalizar su superioridad numérica ante los whigs, lastrados por su desorganización y profunda división interna, presentando sus diversas facciones concepciones antagónicas sobre qué era y cómo debía actuar políticamente un tory (Holmes, 1969, pp. 247-257). De hecho, aunque en 1712 lograron controlar parcialmente a los Country Tories y al October Club, su facción más radical, que buscando alejar a Harley de las políticas moderadas había realizado ofensivas parlamentarias haciéndoles perder incluso el control de la Cámara de los Comunes en 1711, todo apuntaba a que en el nuevo curso parlamentario volverían a mostrarse más exigentes (Dickinson, 1970b, pp. 160-169; Szechi, 1984, pp. 71-96, 120-122). No menos importante era que la fractura entre Harley y Bolingbroke, iniciada en 1708 por sus diferencias sobre como atacar a la Whig Junto y ampliada al decidir Harley mantenerle inicialmente fuera del nuevo gabinete y posteriormente de la negociación de paz, parecía insalvable tras sus encontronazos respecto a cómo finalizarla, el papel de Bolingbroke en el desastroso ataque a Quebec y las sospechas de su acercamiento al October Club como medio de asaltar el liderazgo tory (Holmes, 1969, pp. 269-270; Gregg, 1980, pp. 358-360; Hill, 1988, pp. 150-151, 187-189).

Monteleón solo era parcialmente consciente de esta situación. Ajeno a la mala relación entre Harley y Bolingbroke consideraba, al primero, líder del Consejo Real «arbitro de la voluntad y confiança de la reina, solo depositario de sus secretos y dispotico de todo el poder, dinero y oficios», al segundo, su máximo colaborador y

AMAE, Correspondance Politique, Angleterre, 242, f. 217, Monteleón a Torcy 9-XII-1712. AMAE, Correspondance Politique, Angleterre, 242, f. 246v, sin remitente, 20-XII-1712.

Parke, 1798, vol. 3, pp. 206, 208, Bolingbroke a la reina, 1/12 y 2/13-XII-1712. 
confidente y a ambos únicos conocedores de la voluntad real. Esta idea se reforzó durante la negociación exponiendo como con Dartmouth, pese a ser también Secretario de Estado, únicamente recibía copias de lo tratado en Madrid y encallaban en puntos rápidamente solucionados al retomarlos con Harley o Bolingbroke. Por ello, estaba convencido de que ambos decidían todos los asuntos, aunque por motivos formales en ocasiones cediesen la autoridad teórica a colaboradores que seguían sus instrucciones. Sin embargo, debían lidiar con el Parlamento, independiente e indispensable, puesto que debía aprobar toda resolución que afectase a los intereses del reino, lo que les obligaba a esperar coyunturas favorables para aprobar sus disposiciones. Para Monteleón el ejemplo más claro era como, ante la oposición whig a la paz, Bolingbroke y Harley debieron iniciar los contactos en secreto, «quedando expuestos a perder la cabeza si el negoziado se hubiese descubierto quando aun subsistia con vastantes fuerças el partido de los Wigs» ${ }^{17}$. Esto ayuda a explicar su comprensión cuando rechazaron alguna propuesta escudándose en garantizar su seguridad frente a pesquisas parlamentarias y su convencimiento de que lo firmado por ambos tenía igual valor que si viniese de mano de la reina.

Monteleón pronto fue apreciado por sus interlocutores, definiéndole como habilidoso y honesto aunque muy indiscreto, especialmente con quienes se ganaban su confianza ${ }^{18}$. Reconocieron su buena actitud y disposición a no alargar innecesariamente la negociación ${ }^{19}$ y se mostraron gratamente sorprendidos por su empeño en demostrar la independencia española ${ }^{20}$, encontrándole menos pro-francés de lo esperado ${ }^{21}$ pese a su tendencia a aceptar los consejos de Torcy (Bély, 1990, p. 424).

No fue su única relación con Versalles, que también ordenó al abbé Gaultier, agente francés especialmente implicado en los inicios de la negociación, ayudarle en cuanto precisara (Castellano, 2016, pp. 258-273). Fue una elección acertada, calificándole Monteleón de «instrumento del que se ha valido la providencia para la obra de la paz» ${ }^{22}$, y solicitando recompensarle con una renta de 4.000 ducados, finalmente concedida sobre las rentas del arzobispado de Toledo ${ }^{23}$.

El 21 de diciembre mantuvo su audiencia con Ana de Gran Bretaña, expresándole la amistad y agradecimiento de Felipe V por su esfuerzo en alcanzar una paz justa y su seguridad de restablecer tras ella la amistad hispano-británica. La reina correspon-

AMAE, Correspondance Politique, Anglaterre. 243, ff. 90-92v, Monteleón a Grimaldo, 19-I-1713. AMAE, Correspondance Politique, Angleterre, 243, f. 148v, Aumont a Torcy, 2-II-1713.

B. L., Additional Manuscripts 49971, f. 44v, Bolingbroke a Torcy, 13/24-XII-1712.

B. L, Additional Manuscripts 46546, f. 5, Erasmus Lewis a Lexington, 27-XII-1712. Parke, 1798, Vol. 3, pp. 363-364, Bolingbroke a Strafford, 3/14-II-1712.

AMAE, Correspondance Politique, Angleterre, 244, ff. 201-202, Monteleón a la Corte, 18-IV-1713. AMAE, Correspondance Politique, Espagne, 225, f. 299, extracto de la carta de Grimaldo a Bonnac, 26-VI-1713. 
dió con idénticas buenas palabras, lamentando no poder hacer más por los intereses del rey de España y agradeciendo el recibimiento brindado a Lexington en Madrid. La audiencia finalizó tras una cordial charla entre la reina, Monteleón y su séquito, quedando este encantado por su recepción ${ }^{24}$.

\section{El inicio de la negociación}

Pese a la importancia de actuar con celeridad la negociación tardó varios días en empezar, en buena medida porque Bolingbroke esperaba la llegada de correo con explicitaciones sobre aspectos comerciales tratados por Lexington ${ }^{25}$. También aprovecharon para reunir información útil: Prior — que veía más provechoso tratar con Monteleón, experimentado y con fama de honesto, que con un natural de Castilla ${ }^{26}$-, había aprovechado su viaje a París para reunirse con él cerca de Dover. Gracias a la incontinencia verbal de Monteleón pudo saber que Felipe V aceptaría entregar Sicilia al duque de Saboya sin más condición que no poder enajenarla sin consentimiento español ${ }^{27}$, noticia que produjo gran alivio ya que su intento inicial de mantenerla como terreno feudatario había hecho temer una «tediosa negociación» ${ }^{28}$.

Esto explica que para el 24 de diciembre apenas hubiesen tenido lugar algunas reuniones previas en las que Bolingbroke informó del ultimátum dado a los holandeses, asegurando que si en tres semanas no se sumaban a su plan finalizarían la paz sin ellos. Convencido de la buena disposición británica y su creciente separación con los aliados, Monteleón esperaba esperanzado el inicio de la negociación (Muñoz y Catà, 2009, p. 141).

Por fin, en los últimos días de 1712 comenzó una negociación que pronto confió a los británicos de solventar rápidamente la paz ${ }^{29}$. Monteleón compartía ese optimismo ampliado por las noticias llegadas de Utrecht, donde Holanda concurría a la paz a cambio de una barrera segura y el emperador entraba en negociaciones aceptando el armisticio en Italia, la cesión de Sicilia al duque de Saboya y la evacuación de tropas de Cataluña. Ante un contexto tan favorable tenía claro que debía negociarse rápido, buscando reducir formalidades y que Madrid aceptase las ofertas británicas sin necesidad de que fuesen firmadas por la reina, cuya salud seguía siendo precaria ${ }^{30}$.

\footnotetext{
24 Archivo General de Simancas (en adelante AGS), Estado, leg. 6820. Monteleón a Grimaldo, 22XII-1712.

25 AMAE, Correspondance Politique, Angleterre, 240, f. 285, Bolingbroke a Torcy, 19-XII-1712.

26 B.L, Additional Manuscripts 46537, ff.124-127, Prior a Lexington, 17-X-1712.

27 N.A, State Papers 105/266, ff. 224v-225, Prior a Bolingbroke, 17/28-XII-1712.

28 N.A, State Papers 105/266, f. 202, Dartmouth a Prior, 21-XI/2-XII-1712.

$29 \quad$ Parke, 1798, vol. 3, p. 276, Bolingbroke a Thomas Hanmer, s/f.

30 AMAE, Correspondance Politique, Angleterre, 243, ff. 88-89, Monteleón a Torcy, 19-I-1713.
} 
En lo que se refiere a la negociación, tras los primeros encuentros Monteleón pudo dar cuenta de la satisfacción británica por la resolución de la renuncia de Felipe V al trono francés y la inclusión del duque de Saboya en la línea sucesoria, puntualizando únicamente que veían innecesario pretender la renuncia recíproca del emperador al trono español. Argumentaban que solo le daría una excusa para dificultar el proceso de paz, más cuando era garantía suficiente la nueva línea sucesoria establecida en las Cortes de Madrid y su defensa por parte de todos los príncipes incluidos en la paz. Ante estas razones Monteleón recomendó aceptar el criterio británico y no pedir la renuncia del emperador, salvo que en la paz general solicitase Flandes, Milán o Nápoles.

También existían problemas para fijar los puntos sobre religión en Menorca y Gibraltar pero era optimista en que serían ajustados. Además sobre Gibraltar mantuvo la negativa a entregar terrenos adyacentes, permitir comunicación por tierra, a la entrada o asentamiento de moros y judíos y a dar abrigo o asistencia en puerto a sus embarcaciones. Sin embargo, al tocar su posible recompra fue víctima de la capacidad negociadora de Bolingbroke. Este expuso que no encontraban utilidad a la plaza, pero que al haber sido recibida su toma con gran alegría por una opinión pública que no entendía una guerra sin conquistas debían demostrar su coste y falta de utilidad antes de poder plantear su enajenación.

De igual manera anunció su confianza en conseguir que aceptasen devolver Mallorca, Ibiza y Formentera y respetar el derecho a la investidura del estado de Siena, punto sobre el que se mostraba especialmente optimista y que no carecía de importancia por ser feudatario de dicho estado los presidios de la Toscana, territorio también en disputa y que de extinguirse la Casa del duque de la Toscana - como parecía muy probable ante la falta de heredero- debía revertir en la monarquía hispánica.

Sobre Sicilia la reina insistía en su cesión completa y sin condiciones, pero no tenía objeciones en respetar los derechos y bienes de sus habitantes y que no pudiese enajenarse a más potencia que España. En cambio existían divergencias en la última condición añadida por Felipe V, la garantía de no permitir nuevos desmembramientos territoriales. Aunque Monteleón afirmó que sin asegurar ese punto no habría paz, los británicos expusieron que no podían comprometerse a algo frontalmente opuesto a lo acordado con sus aliados. Pese a ello, aseguraron que siempre habían trabajado sobre la base de que Felipe V mantuviese intactas España e Indias, y sabiendo Monteleón que habían desengañado a Portugal de obtener ganancias territoriales en la península se mostró confiado en obtener esta condición e incluso encontrar formas de fijarlo por escrito.

En el terreno comercial no preveía dificultades respecto al asiento de negros y anunció que les había convencido de lo impracticable de conceder la exención del $15 \%$, aceptando trocarla por alguna ventaja equivalente. Sin embargo, él no podía 
acordarla al quedar el tema en manos de Gilligan, hombre de confianza de Bolingbroke enviado a Madrid para cerrar las materias comerciales, remitiendo nuevamente el asunto a Madrid ${ }^{31}$.

Es necesario mencionar que todo apunta a que Gilligan fue empleado por St. John para obtener beneficios personales a través de una trama corrupta. El propio Bolingbroke le confió que la cuestión comercial quedaba en sus manos ya que, sobornándole, había conseguido que Monteleón aceptase no tratarla ${ }^{32}$. En efecto, tras recibir una renta vitalicia para su hija sobre las ganancias del asiento de negros, no solo devolvió la negociación a Madrid sino que incluso comentó que Lexington no debía conocer lo tratado al respecto ${ }^{33}$, petición sumamente extraña siendo aquel el negociador principal británico. Que a su regreso también Gilligan obtuviese una renta vitalicia sobre dicho asiento y no informase al Board of Trade and Plantations de su contenido apunta a que, como en otras empresas turbias ${ }^{34}$, en la negociación del asiento de negros existieron intereses y comisiones relacionados con Bolingbroke (Fernández, 2011, pp. 111, 123).

Por último, respecto a la cuestión catalana Dartmouth insistió en cuanto les sorprendía la obcecación mostrada en abolir sus privilegios. Expuso que siendo obvio que Felipe $\mathrm{V}$ no pasaría por las armas toda una provincia la amnistía no podía tener más sentido que garantizar sus libertades, insistiendo en la importancia que la reina concedía a ese punto ${ }^{35}$. Sin embargo, Monteleón confirmó que el rey estimaba suficiente asegurar vidas, honores y bienes particulares, dado que los catalanes, además de haberse mostrado indignos de mantener sus leyes y privilegios, de conservarlos podrían hacer peligrar la tranquilidad de España e incluso de la propia Inglaterra por haberse vinculado al destino de esa provincia ${ }^{36}$.

En resumen, tras las primeras negociaciones Monteleón se mostraba optimista, lamentando únicamente la tardanza en pasar a Gran Bretaña. Opinaba que de haber llegado antes un ministro de Felipe $\mathrm{V}$ a Londres, la situación estaría ya resuelta y en mejores condiciones para sus intereses, puesto que ahora los británicos debían mantener compromisos suscritos con otras potencias. Sin embargo estaba convencido de su simpatía, aventurando que si tras la paz mantenían la amistad con Gran Bretaña y Francia podrían recuperar gran parte de los territorios perdidos ${ }^{37}$.

\footnotetext{
31 AMAE, Correspondance Politique, Angleterre, 243, ff. 92v-97, Monteleón a Grimaldo 19-I-1713.

32 Parke, 1798, vol. 3, pp. 329-330, Bolingbroke a Gilligan, 25-I-1713.

33 AMAE, CP. Angleterre, 243, f. 94v, Monteleón a Grimaldo, 19-I-1713.

34 Varias empresas relacionadas con Bolingbroke presentaron evidencias de corrupción. Por ejemplo la expedición naval contra Quebec de 1711 presentó un sobrecosto de más de 21.000 libras en los contratos de bastimentos de ropa (Trevelyan, 1934, vol. 3, p. 119; Dickinson, 1970a, pp. 13, 83).

35 N.A. State Papers 105/270, ff. 37-38, extracto de la carta de Dartmouth a Monteleón, 14-I-1713.

36 AMAE, Correspondance Politique, Angleterre, 243, f. 109v, Respuesta de Monteleón a Dartmouth, 25-I-1713.

37 AMAE, Correspondance Politique, Angleterre, 243, ff. 96-97, Monteleón a Grimaldo 19-I-1713.
} 
Tres días después volvió a escribir a Madrid para mostrar las respuestas británicas al proyecto de evacuación de Cataluña y neutralidad en Italia presentado en Utrecht por Sinzendorf.

Los siete primeros puntos concretaban la evacuación y se calificaban de razonables. Así, se establecería un alto el fuego hasta que la emperatriz y sus tropas abandonasen el lugar, realizándolo lo más rápidamente posible en un convoy provisto por la reina Ana. Las tropas y quienes quisieran seguirles podrían pasar libremente con sus pertenencias, y aunque se nombrarían comisarios para asegurar el pago de deudas no se impediría marchar a nadie por esta causa. Igualmente se intercambiarían prisioneros y los enfermos y heridos serían atendidos hasta su total recuperación, garantizándoseles después una salida segura del territorio. Por último, todo lo referente a la evacuación y transporte de tropas que debiese reglarse sería remitido a los almirantes y generales encargados, teniendo su decisión carácter definitivo.

Los restantes puntos sí presentaban dificultades. Los británicos negaban el octavo artículo que solicitaba el salvis addendis y en el noveno, que buscaba mantener los privilegios catalanes, Monteleón únicamente aceptó acordar «el perdón de los catalanes».

Los artículos 10 al 15 quedaban aprobados a expensas del visto bueno de Madrid y siempre que se hiciesen extensivos a los borbónicos en territorio austracista. Demandaban amnistía general para los españoles y catalanes que habían servido al emperador, teniendo libertad de movimiento, conservando vida, bienes, haciendas, herencias, restituyéndoseles los bienes embargados y pudiéndolos vender, cambiar o alienar los que marchasen. Se conservarían las dignidades, oficios, y beneficios eclesiásticos y seculares otorgados por el emperador, pudiendo disfrutarlos sus poseedores incluso en ausencia, y quedarían exentos del pago de Lanzas los grandes y nobles que apoyaron al emperador y decidiesen quedarse en España.

Para asegurar la tranquilidad de la península italiana, los británicos aceptaban que el emperador retirase «todas sus tropas que no sean necesarias para la guarda de sus plazas»; dieron seguridades recíprocas de no agresión y por último remitieron al acuerdo general de paz la propuesta de que cuando el emperador evacuase Cataluña, Francia y sus aliados retirasen sus tropas en Italia ${ }^{38}$.

Por otra parte, el 5 de febrero se enviaron las respuestas de la reina a los puntos presentados por Monteleón. El acuerdo era total respecto al reconocimiento de la sucesión protestante a la corona británica y la renovación de los antiguos tratados de amistad, y sobre las condiciones demandadas para no pedir la renuncia del emperador al trono de España, la reina aceptó ser garante del cumplimiento de la sucesión

38 AMAE, Correspondance Politique, Angleterre, 243, ff. 105-108, Monteleón, 22-I/2-II-1713. 
establecida en las Cortes y que aún así el emperador debiese realizarla de pretender la renuncia de Felipe V a Flandes ${ }^{39}$.

Sobre la religión en Menorca recordaron que su libre ejercicio ya fue prometido por el duque de Argyll quien, tras ser instruido para asegurar la religión, leyes propias y libertades de la isla, tomó posesión de ella en noviembre de 1712, comunicando a sus autoridades que quedaban bajo soberanía británica (Vidal, 2014, pp. 185-186). Sea como fuere renovaron esta promesa, aceptando todo expediente necesario para preservar el catolicismo compatible con el gobierno civil y las leyes británicas. Esto provocó gran controversia, pues algunos ministros no consideraron honroso aceptar condiciones en una plaza conquistada por las armas, aconsejando Monteleón actuar con cautela para no provocar reacciones contrarias a la disposición (Guerrero, 2008, p. 487).

Respecto a Gibraltar se acordó no permitir establecerse a judíos y moros ni alojar barcos de estos últimos, se consagró el libre ejercicio de la religión católica y, de ser alienada, España tendría preferencia para adquirirla.

Sobre Sicilia se aceptó que la cesión fuese únicamente sobre la línea masculina, revirtiendo en su falta a España, y la prohibición de enajenarla a ninguna otra potencia.

Más dificultades encontró Monteleón para obtener garantías de que no habría más desmembramientos territoriales, ya que, si bien le aseguraron haber tomado medidas para impedirlo, se negaban a garantizarlo por escrito.

En los artículos comerciales el acuerdo era total, aceptando los británicos desistir de la exención del 15\%, si se acordaban en Madrid los puntos que Gilligan propusiera a cambio.

Por otra parte, si bien la reina vio razonable la propuesta de Felipe V de añadir un artículo garantizando a sus súbditos en zonas austracistas restablecimiento de bienes y honores, libre disposición de bienes y libertad para seguir a su servicio fuera de esos territorios o regresando a sus dominios, reiteró su obligación con los catalanes. Así, aunque veía positivo el perdón acordado recordaba que ya la amnistía general propuesta por Francia en abril de 1712 implicaba la conservación de privilegios. Se insistió en que había empeñado su honor y que tras retirar sus tropas y preparar la salida de las tropas imperiales de Cataluña esperaban que, en agradecimiento, satisficiesen su petición de dejarles en el mismo estado que cuando se inició la guerra.

Aceptaba también los nuevos artículos solicitados por Felipe V: conservar el derecho a conceder la investidura de Siena, esperando que a cambio tomase las medidas más adecuadas para mantener el equilibrio de poderes en Italia; devolver Mallorca, Ibiza y Formentera a cambio de que Menorca fuese abastecida a precio razonable,

La petición de Monteleón incluía Nápoles y Milán, obviados en la respuesta y que sí había concedido Lexington en el artículo $\mathrm{n}^{\mathrm{O}} 2$ del preliminar de Madrid. 
mantener el derecho de pesca de ballena y bacalao en Terranova y apoyar la concesión de la soberanía a la princesa de los Ursinos, sin consentir la evacuación de Baviera hasta que no se hallase en su posesión.

Se añadió también un asunto de última hora de gran importancia para los británicos: el permiso concedido a seis barcos franceses para comerciar con la América española. Recordaron que era imprescindible que ninguna otra potencia tuviese privilegios comerciales allí, y enterados de que España recibiría 360.000 coronas o esos seis barcos una vez finalizada su labor, instruyeron a Gilligan para proponer formas de conseguir esa suma e incluso ofrecer seis barcos, pero siempre asegurando que el permiso comercial fuese cancelado ${ }^{40}$.

Monteleón, además de informar a Torcy de la necesidad de revocarlo ${ }^{41}$, remitió a Madrid amplia información sobre la South Sea Company instando a deshacer el acuerdo. Afirmó que pondría en peligro toda la negociación, compartiendo además sus sospechas de que de romperse la tregua la marina británica se lanzaría a tomar territorios en las Indias españolas (Muñoz y Catà, 2009, p. 161; Fernández, 2011, pp. 144-145).

El problema se resolvió más rápida y sencillamente de lo que podía parecer, y mientras Felipe $\mathrm{V}$ encargó a Monteleón anular los pasaportes concedidos y confirmar a los británicos su decisión de no permitir a ninguna potencia comerciar con las Indias ${ }^{42}$, desde Francia Torcy ordenó la disolución del contrato ${ }^{43}$.

Visto el desarrollo de los acontecimientos, Monteleón estaba tremendamente confiado en alcanzar un final satisfactorio para la negociación y, mientras esperaba la respuesta de Felipe V, continuó realizando gestiones. Parecía ineludible reforzar las instancias sobre la soberanía para la princesa de los Ursinos, ya que Torcy había comentado que «los plenipotenciarios ingleses en Utrecht ríen cuando se habla del tema, y es necesario tratarlo más seriamente para hacerlo aprobar» ${ }^{44}$. Por ello solicitó a los ministros de la reina ordenar a sus plenipotenciarios defender dicha concesión, que debería otorgarse en Limburgo por garantizar la independencia la princesa al estar separado de Francia por Luxemburgo, aceptando desgajar una parte si excedía de los 30.000 escudos de renta o añadir territorios de no llegar a dicha cantidad ${ }^{45}$. Bolingbroke aseguró que había ordenado que pasara a ser condición sine qua non para

$40 \quad$ AMAE, Correspondance Politique, Angleterre, 243 ff. 110-117. Proposición hecha por el marqués de Monteleón y respuestas de la reina de Gran Bretaña, 25-I/5-II-1713.

41 AMAE, Correspondance Politique, Angleterre, 243 f. 153, Monteleón a Torcy, 6-II-1713.

42 AMAE, Correspondance Politique, Angleterre, 244 ff. 24v-25, Monteleón a Torcy, 1-III-1713.

43 Parke, 1798, Vol.III, p. 405, Shrewsbury a Bolingbroke, 16-II-1713.

44 AMAE, Correspondance Politique, Angleterre, 244, f. 29, Torcy a Monteleón, 8-III-1713.

45 AMAE, Correspondance Politique, Angleterre, 244, f. 27, copia de la memoria sobre Ursinos presentada por Monteleón a los ministros de la reina. 
la paz, y Monteleón solicitó a Torcy que también sus plenipotenciarios apoyasen una resolución que tanto importaba a Felipe $\mathrm{V}^{46}$.

El 27 de febrero llegó la respuesta de Madrid al tratado de evacuación de Cataluña. Felipe V aceptó la suspensión de armas hasta el embarque de todas las tropas, dando un mes para la evacuación desde la firma del tratado y garantizando su abastecimiento a los precios corrientes. Permitía también evacuar toda la impedimenta salvo la artillería, cañones, morteros y toda arma tomada desde su llegada a la península. Si finalmente Gran Bretaña no proporcionaba el transporte debería costearlo Carlos VI, y si tras acordar el tratado surgía algún nuevo problema los responsables designados por ambas partes tendrían total capacidad de decisión.

Aceptaba también el intercambio de prisioneros de guerra, que heridos y enfermos fuesen cuidados hasta su recuperación, permitiéndose entonces su marcha y que no se pudiese detener por deudas a quien quisiera ser evacuado, siempre que los rehenes o fianzas dejadas para asegurar su cobro satisficieran a los comisarios que se designarían para ello.

Como era de esperar Felipe V se negó a mantener los privilegios catalanes, ofreciendo únicamente amnistía, perdón y conservación de bienes y emplazando al tratado general de paz sus concreciones. Tampoco aprobó que los nobles austracistas que quedasen tras la evacuación estuviesen exentos de pagar el subsidio de Lanzas ni mantener las dignidades, oficios, beneficios eclesiásticos y seculares y pensiones sobre los obispados otorgados por el emperador.

Por último, admitió la neutralidad en los territorios italianos y la retirada de las tropas imperiales de la zona — quedando a convenir el número- pero aplazando a la paz general la retirada de las tropas francesas y españolas, y aprovechó para solicitar nuevamente la aceptación de sus plenipotenciarios en Utrecht, afirmando haber hecho suficientes concesiones en favor de la paz como para no retrasar más la expedición de sus pasaportes ${ }^{47}$.

La respuesta de Carlos VI allanó gran parte de las dificultades que quedaban al comprometerse a entregar como garantía de su salida Tarragona o Barcelona al inicio de la evacuación a cambio de eliminar el plazo de un mes para completarla ${ }^{48}$. Así las cosas, solo la cuestión catalana evitaba el acuerdo total e incluso los plenipotenciarios de Felipe $V$ estaban cerca de ser admitidos en Utrecht, ya que a primeros de febrero los holandeses aceptaron enviar sus pasaportes, siempre que fuera solicitado por Francia, que los demandó una semana después ${ }^{49}$.

\footnotetext{
46 AMAE, Correspondance Politique, Angleterre, 244, ff. 90v-91, Monteleón a Torcy, 19-III-1713.

47 B. L. Additional Manuscripts 46549, ff. 101-107, Respuesta de Felipe V a la propuesta de evacuación de Cataluña, 9-II-1713.

48 AMAE, Correspondance Politique, Espagne, 220 f. 105, Luis XIV a Bonnac, 20-II-1713.

49 N.A. State Papers 105/271, s/n, los plenipotenciarios a Bolingbroke, 14-II-1713.
} 


\section{Accrochée par des bagatelles: La paz preliminar se demora}

La sensación de que el acuerdo era casi un hecho era compartida, y Bolingbroke esperaba que cuando Monteleón recibiera la respuesta a sus últimas cartas no quedase más que firmarlo ${ }^{50}$. Por ello ordenó a Strafford insistir en que no se retardase más la expedición de pasaportes a los plenipotenciarios españoles y mantenerse firme en la cuestión catalana, convencido de que harían cambiar de parecer a Felipe $\mathrm{V}^{51}$. Repitió esto último a sus plenipotenciarios en Utrecht, asegurando que la reina no abandonaría esa petición bajo ninguna circunstancia ${ }^{52}$. Su convencimiento se reafirmó tras concebir con Monteleón la que parecía solución definitiva al problema: evitar usar Privilegia Omnia, que englobaría todos los privilegios catalanes, incluyendo los obtenidos en las Cortes de 1701 y 1705, empleando en su lugar Privilegia Antiqua. Esta denominación, más ambigua, podría interpretarse en sentido amplio y referirse a cualquier privilegio otorgado en tiempo alguno, permitiendo restringir las libertades catalanas salvaguardando el honor británico al introducir la expresión «privilegios» (Albareda, 2015, p. 85).

Sin embargo, Felipe V se negó a incluir nada que pudiese dar pie a una interpretación favorable a los intereses catalanes. Su negativa aumentó la impaciencia británica y francesa, convenciendo a Bonnac, embajador francés en Madrid, de que sin presionar conjuntamente a Felipe $\mathrm{V}$ la negociación no acabaría jamás y fiándolo todo al buen hacer de Monteleón ${ }^{53}$.

Fue finalmente una sugerencia francesa la que permitió cierto desbloqueo. Se apuntó que al no ser la cuestión catalana esencial para resolver la evacuación de las tropas imperiales podía emplazarse a la negociación de la paz general en Utrecht o cuando menos a la particular hispano-británica, argumento aceptado por Felipe V y gracias al que el 14 de marzo se rubricó el tratado de evacuación de Cataluña ${ }^{54}$.

En la aprobación de este esquema también fue importante el hartazgo imperial, actuando de modo muy distinto que al conocerse los Preliminares de Londres. Si entonces Carlos VI buscó que los restantes aliados presionasen a Gran Bretaña contra ellos y el mariscal Starhemberg intentó impulsar la guerra peninsular (León, 2013, p. 105), ahora Sinzendorf ya había planteado que «de la misma manera que a dos que se ahogan no se puede pedir al que pueda salvarse que se pierda por el otro, así se ha debido abandonar a los catalanes» (Sanpere, 1905, p. 50), y el propio emperador

Parke, 1798, vol. 3, p. 306, Bolingbroke a Prior, 19/30-I-1713.

Ibidem, p. 365, Bolingbroke a Strafford, 3/14-II-1713.

B.L. Additional Manuscripts 22206, s/n, Bolingbroke a sus plenipotenciarios, 13-II-1713.

AMAE, Correspondance Politique, Espagne, 220, f. 109, Bonnac a Torcy, 13-II-1713.

AMAE, Correspondance Politique, Espagne. 225, f. 106, Luis XIV a Bonnac, 20-III-1713. 
encargó a Starhemberg interceder por los catalanes, pero sin retardar el embarque de tropas (Albertí, 1964, p. 115).

No todos aprobaron esta actuación y el conde de la Corzana, plenipotenciario imperial, se negó a firmarlo apuntando:

\begin{abstract}
el tiempo no borrará el sacrificio que el Ministerio Inglés hace de la España, y singularmente de la Corona de Aragón, y más en particular de la Cataluña, a quienes la Inglaterra ha dado tantas seguridades de sostenerles y ampararles [...] a más de manchar el honor de la Inglaterra aumenta las fuerzas á los Borbones, quedando aquellos países sin Privilegios; y el reservar tratar de este punto á la Paz General es un pretexto muy poco pálido y una esperanza mal fundada porque el opio del Perú y Potosí que de presente a adormecido al ministerio inglés para sacrificar los intereses de los aliados, el honor y la conveniencia de su patria, no ha agotado por este acto las minas y tesoros de los Borbones ${ }^{55}$.
\end{abstract}

Pese a este paso adelante la falta de avances en la negociación del preliminar de paz incrementó la presión sobre Monteleón, especialmente cuando el 11 de abril se concluyó en Utrecht la paz franco-británica ya que Harley y Bolingbroke pretendían que la reina pudiese anunciar al Parlamento al mismo tiempo ambas paces.

El problema para Monteleón era que llevaba casi dos meses sin noticias de Madrid, pero temiendo que pudiera darse un vuelco político que devolviese a los whigs al poder, decidió junto a Bolingbroke y Harley actuar desde la buena fe para evitar «la monstruosidad de que se declarase y publicase la paz particular con la Francia y no se executase lo mesmo por la España». Así, actuando por propia iniciativa, decidió aceptar un tratado provisional acorde a las últimas peticiones recibidas.

De este modo, acordó que el comercio de Indias sería realizado solo por España, dejando toda puntualización a convenir en Madrid con Gilligan. Mucho más riesgo corrió al aceptar como gracia de Felipe $\mathrm{V}$ a la reina Ana la concesión a los catalanes de sus antiguos privilegios, si bien añadió una declaración especificando que, siendo contrario a sus órdenes, quedaba sin valor hasta ser expresamente aprobado por el rey de España.

Para limitar las críticas de Madrid aseguró que había conseguido unas seguridades sobre la religión y las restricciones solicitadas mucho más fuertes que en los textos del 5 de febrero, y reiteró que actuaba así por ser la única posibilidad de declarar ambas paces y sin aventurar nada al dejarlo pendiente de la aprobación real.

Aún así, decidió retrasar hasta el último momento su firma, esperando que en ese tiempo llegase el correo de Madrid con las instrucciones sobre lo realizado el 5

55 Castellví, (ed. 1997-2002), vol. 3, p. 520 
de febrero. En caso contrario esperaría a la arenga de la reina en el Parlamento para remitir su informe y la copia del tratado provisional, partiendo hacia Utrecht tras recibir las últimas respuestas de Madrid $^{56}$.

Esa decisión fue vital, ya que la reapertura del Parlamento se retrasó en varias ocasiones hasta fijarse para el 20 de abril, permitiendo reaccionar a la corte española. Al conocer lo sucedido Bergeyck, firme defensor de no restablecer las leyes catalanas, insistió en que debió haber explicado mejor los «perjuicios irreparables que tendría para su soberanía y la tranquilidad de sus Reinos» y criticó que no hubiese esperado a la llegada del acuerdo preliminar de Madrid. Tampoco entendía que Monteleón debiera asumir riesgos, convencido de que cualquier facción política británica firmaría la paz ante los beneficios comerciales que iban a obtener y haciéndoles únicos culpables del retraso por haber bloqueado tanto tiempo la negociación directa entre ambas cortes ${ }^{57}$. Bergeyck, cuya independencia frente a Versalles le había hecho ganar ascendencia a ojos de Felipe V, se había opuesto frontalmente a la intermediación francesa viendo preferible negociar directamente con Holanda y llegando a solicitar a Bonnac la devolución del Rosellón (Baudrillart, 1890, Vol. I, pp. 456-461). Esto explica tanto sus críticas a Monteleón, a quien consideraba demasiado complaciente con los deseos franceses, como que desde tiempo atrás Versalles insistiese en que debían frenar su radicalidad $^{58}$.

Mientras esperaba noticias de Madrid y el momento de firmar el preliminar Monteleón siguió trabajando. Así, consiguió el apoyo británico a la conservación de Puerto Longone y pareció asegurar la soberanía de la princesa de los Ursinos, siendo informado de que los plenipotenciarios británicos habían recibido la confirmación de que el emperador aceptaba concederla ${ }^{59}$.

Además, informó de que el emperador parecía dispuesto a aceptar el plan de paz de la reina, exigiendo únicamente la devolución de los muebles y alhajas del palacio de Baviera y, respecto a España, no incorporar nada relacionado a renunciaciones y la cesión de los presidios de Toscana. Para Monteleón eran movimientos favorables, opinando que Puerto Longone podría ser moneda de cambio para asegurar el derecho de investidura de Siena y viendo con buenos ojos la ausencia de renuncias en la península italiana, ya que preveía allí una situación muy tensa tras la paz que favore-

\footnotetext{
56 AMAE Correspondance Politique, Angleterre, 244, ff. 93-95, copia de la carta de Monteleón a Grimaldo, 19-III-1713.

57 AGS, Estado, leg. 6822, Bergeyck a Grimaldo, 7-IV-1713.

58 AMAE Correspondance Politique. Espagne. 215, f. 119, Torcy a Bonnac, 22-VIII-1712. Ya antes Luis XIV había comentado al respecto a su nieto (Guillamón y Muñoz, 2008, p. 181).

59 AMAE, Correspondance Politique, Angleterre, 244, f. 151, copia de un billete escrito por Bolingbroke a Monteleón, 2-IV-1713.
} 
cería su restitución a España para asegurar la tranquilidad en la zona. Solo albergaba la sospecha de que su oferta fuese un pretexto para no renunciar al título de rey de España, manifestando que en tal caso no firmarían la paz con el emperador e instando a Madrid a finalizar cuanto antes la evacuación de Cataluña por darles una ventaja estratégica clave ${ }^{60}$.

Cuando Monteleón volvió a recibir correspondencia de Madrid debió sentirse aliviado al comprobar que Felipe $\mathrm{V}$ aceptaba su actuación para permitir a los británicos anunciar la paz conjunta, siempre que efectivamente quedase a expensas de su aceptación. Además recibió la información del acuerdo comercial, una copia del preliminar firmado con Lexington e instrucciones para negociar los artículos que no habían sido acordados.

Estas le indicaban procurar mantener Sicilia como feudo real, asegurando idéntica capacidad para Malta por ser feudo de Sicilia. Aún así, estaba autorizado a aceptar una negativa de ser imposible el acuerdo.

Más hincapié se hacía en ser la única potencia a la que pudiesen vender Gibraltar o Menorca, ya que Lexington solo había consentido otorgar la preferencia, pero el punto en que más se centraron fue la cuestión catalana. Respecto a los seguidores de Carlos VI se admitió — de ser recíproco — restituir rentas, bienes y posesiones y garantizar su libre disfrute, pero únicamente a través de administradores y sin admitirse su regreso bajo ninguna circunstancia. Tampoco se mantendrían los cargos y beneficios eclesiásticos concedidos por el emperador, ya que tras ser asesorado por una junta de teólogos y el confesor real Felipe $V$ concluyó que no era admisible para su conciencia ${ }^{61}$.

Y como era de esperar se cerró en banda a negociar la devolución de privilegios y leyes a los catalanes:

en ninguna forma viene ni vendrá en expediente convenio ni Tratado alguno, que mude de lo que tiene determinado y resuelto en esto, manteniéndose firme en la deliberación tomada, sin diferir a la proposición o palabra propuesta de privilegios antiguos ni a otra ninguna [...] en cuanto a los fueros de los catalanes, no viene, ni vendrá S. M nunca, no solo en concedérselos, pero ni aun en admitir, ni convenir, a que se ponga palabra, ni expresión que aluda a ellos, ni les deje ninguna abertura, ni esperanza ${ }^{62}$.

Siendo necesario modificar los aspectos considerados inaceptables, Monteleón solicitó una reunión con Bolingbroke, encontrando su contrariedad ante varios de los

\footnotetext{
60 AMAE, Correspondance Politique, Angleterre, 244, ff. 154v-155, copia del despacho de Monteleón a Grimaldo, 2-IV-1713.

$61 \quad$ AGS, Estado, leg. 6822, Grimaldo a Monteleón, 28-III-1713.

$62 \quad$ Ibídem.
} 
nuevos términos. Declaró que excluir los navíos comerciales moros contravendría las leyes de Inglaterra y sus tratados con Berbería y que era imposible admitir la mayor parte de lo propuesto sobre religión en Menorca y Gibraltar, expresando que habiendo ya acordado mantener el catolicismo como se encontraba antes de la conquista, el artículo solo podría consignarse en términos muy generales.

También mostró su contrariedad respecto al caso catalán pero presentando su postura un cambio esencial: no pretendía ya confirmar sus privilegios sino únicamente añadir los matices necesarios para salvar el honor de la reina aunque la disposición permitiese a Felipe V actuar contra ellos. Acabada la reunión, St. John le informó que explicaría lo hablado a la reina y le remitiría su respuesta a la mayor brevedad posible. ${ }^{63}$

Dos días después se produjo un nuevo encuentro al que acudió con pocas esperanzas, pues Bolingbroke le comentó que si él veía puntos inaceptables, pensara en el ánimo de los ministros menos propensos a concesiones ${ }^{64}$. El británico expuso que tras dos largas reuniones el Consejo Real había encontrado dificultades en algunos artículos preliminares firmados en Madrid y tres problemas en el tratado de Asiento. Estos se iniciaban con las condiciones pretendidas en la cesión de los puertos de Gibraltar, Mahón y la isla de Menorca, negándose a excluir el comercio con los moros, aunque aceptando no acoger ni ayudar a corsarios o piratas para evitar amenazas sobre Ceuta o la costa española. Igualmente aceptaban no permitir establecerse a judíos o moros en Menorca, pero por motivos comerciales debían poder acceder durante ciertas horas al día. Tampoco logró Monteleón ningún avance en su pretensión de que solo pudiesen ser enajenados a España.

Encontró otra firme negativa a incluir añadidos respecto a la religión católica por considerarlo contrario a las leyes y reglas del buen gobierno, habiendo amenazado el Consejo Real en pleno con dimitir antes que aceptarlo. Bolingbroke explicó que, de aceptarlos, los whigs podrían acusarles de allanar la sucesión católica al trono por lo que únicamente podían ofrecer una cláusula general, lo más clara posible, garantizando el ejercicio del catolicismo en el estado en que se encontraba antes de la conquista. Aunque Monteleón intentó que al menos aceptasen añadir lo admitido por Lexington, por ser indispensable para ejercer y mantener la religión católica ${ }^{65}$, recibió una tajante

63 AMAE, Correspondance Politique, Angleterre, 244, ff. 222v-223, copia de la carta de Monteleón a Felipe $V, 26-I V-1713$.

64 Parke, 1798, vol. 4, p. 27, Bolingbroke a Monteleón, 7/18-IV-1713.

65 El artículo 5 del preliminar de Madrid acordó mantener, aun de haber nueva guerra, las dignidades y beneficios eclesiásticos y su sucesión y los conventos religiosos, respetándose sus reglamentos y pudiendo incorporar novicios. Obispos, diocesanos y vicarios ejercerían libremente sus funciones y las vacantes de dignidades y oficios eclesiásticos recaerían en cristianos católicos, apostólicos y romanos elegidos por el monarca británico entre una terna de candidatos presentada por el obispo de la diócesis. 
respuesta: no lo aprobarían bajo ninguna circunstancia y si no cedía en este punto se limitarían a proclamar su derecho de conquista sobre ambos territorios. Aún así, realizó un último intento al proponer que el tratado general de paz hiciese constar ese libre uso y ejercicio del catolicismo y consignar los expedientes necesarios en un artículo particular secreto. Bolingbroke se limitó a comunicar que lo comentaría a la reina y le informaría de su decisión.

En cuanto a las leyes y privilegios catalanes explicó que debían encontrar una solución que conservase el honor de la reina sin perjudicar la intención de Felipe $\mathrm{V}$ de establecer una única ley en todos sus dominios. Tras exponer Monteleón que el rey rechazaba el término «privilegios antiguos», por saber que cualquier alusión serviría de pretexto a los catalanes para mantener su actitud sediciosa, presentó una nueva propuesta. Además de la vida, bienes y honores acordados en el Perdón General les dejarían sus leyes civiles salvo aquellas leyes y privilegios opuestas a la soberanía y regalía, concediéndoles igual trato que a aragoneses y valencianos y pasando a gozar de todos los privilegios que disfrutaban los castellanos. Bolingbroke, deseoso de zanjar un punto tan conflictivo, se comprometió a hacer lo posible para conseguir un acuerdo.

Pese a que esos eran los principales escollos también trataron tres cuestiones derivadas del tratado del asiento: que la redacción de los artículos 31 y 36 podía dar lugar a errores y a la existencia de algunas restricciones comerciales mayores de las que tenían los franceses. Solventarlos no fue problemático, garantizando Monteleón que podrían eliminar esas partes y añadir las explicaciones que considerasen necesarias siempre que no modificasen el espíritu del artículo.

Aunque con eso se habían cubierto todos los puntos a negociar aún tuvo lugar otro hecho especialmente relevante. Ante la preocupación por lo que acontecería cuando al día siguiente la reina confirmase al Parlamento que no había concluido la negociación con España, Monteleón decidió actuar nuevamente de forma autónoma. Aseguró que dada la buena fe mostrada por ambas partes se comprometía a allanar cuanto pudiese las dificultades existentes y confiaba que Felipe V aprobaría el servicio que estaba realizando por concluir la paz. Así, siendo únicamente cuestión de tiempo cerrar el acuerdo, bien podía anunciarse que la paz con España también había sido finalizada. Esta solución improvisada fue agradecida por Bolingbroke y admitida por el Consejo Real y la reina ${ }^{66}$, quien en efecto al día siguiente anunció la conclusión de ambos tratados.

Pero que la apertura parlamentaria hubiera sido salvada no obviaba que la paz seguía sin ajustarse, y Bolingbroke insistió en que era necesario encontrar un acuerdo definitivo:

AMAE, Correspondance Politique, Angleterre, 244, ff. 223-226v, copia de la carta de Monteleón a Felipe V, 26-IV-1713. 
il est absolument nécessaire que nous trouvions quelque tempérament sur l'article des Fueros des Catalans, \& sur celui de la religion dans l'Isle de Minorque \& à Gibraltar. Il seroit en vérité, Monsieur, trop dur, de voir une négociation, conduite jusques ici si heureusement, accrochée par des bagatelles, j'ose appeller ainsi tout ce qui arrête la conclusion de la paix entre nos deux nations ${ }^{67}$.

Por ello presentó dos ofertas. Por una parte, si Felipe V cedía formalmente Menorca y Gibraltar los bienes, privilegios y honores civiles y eclesiásticos, así como la religión católica, serían asegurados mediante una estipulación formal. La segunda pretendía cerrar ambos temas al unísono: aceptarían su propuesta sobre los privilegios catalanes, si resolvían la cuestión religiosa con una estipulación genérica garantizando libre ejercicio y conservación. Sin embargo, también dejó claro que de insistir en las condiciones anteriores, aplicarían el derecho de conquista y dejarían lo referente a la religión en manos de las autoridades religiosas protestantes ${ }^{68}$.

Monteleón volvió a razonar los puntos de desencuentro. Sobre los privilegios catalanes, siendo necesario eliminarlos para asegurar el buen gobierno de sus territorios, proponían otorgar perdón y el mismo trato que a aragoneses y valencianos, a quienes se había concedido los privilegios castellanos. Añadió que viendo la importancia que Felipe $\mathrm{V}$ daba a este punto la mayor muestra de amistad que podían ofrecerle era dejar de insistir en la conservación de las leyes catalanas.

Sobre la religión recordó que solo pretendía insertar cuestiones aceptadas por Lexington e imprescindibles para su libre ejercicio y conservación. Argumentó que podrían justificarlo diciendo que actuaban siguiendo los expedientes realizados en otros casos parecidos y que esa decisión no afectaría a la reina, al ser bien sabido que en asuntos religiosos delegaba en sus ministros eclesiásticos. Por ello, y pidiendo especial delicadeza en un asunto tan importante para los españoles como su religión «a la que estaban muy atados y eran muy escrupulosos», propuso insertar la conservación de la religión, honores y privilegios civiles y eclesiásticos en la declaración general y los expedientes necesarios en un artículo separado ${ }^{69}$.

En la siguiente reunión se dio un paso clave para cerrar el acuerdo. Bolingbroke comunicó que el Consejo Real se mantenía firme en no añadir explicaciones respecto a la conservación de la religión católica pero quedarían satisfechos resolviendo la cuestión catalana con la concesión de los privilegios castellanos.

Era un avance doblemente importante para los intereses de Felipe V, ya que en esas fechas había llegado a Londres el marqués de Montnegre para defender los dere-

Parke, 1798, vol. 4, pp. 33-34, Bolingbroke a Monteleón, 11/22-IV-1713.

Ibidem, pp. 33-36.

AMAE, Correspondance Politique, Angleterre, 244, ff. 230-231, copia de la respuesta de Monteleón a St. John, 26-IV-1713. 
chos catalanes y solicitar la conformación de una república del Principado de Cataluña o que, de quedar bajo dominio borbónico, se reconociesen las constituciones y privilegios concedidos por Carlos II y las leyes de Aragón, Valencia y Mallorca (Albareda, 2000, pp. 71-72). Pero Monteleón había actuado con presteza introduciendo entre sus hombres de confianza a un espía, D. Pascual Antón, e informado de sus movimientos hizo saber a Bolingbroke las intenciones del enviado catalán. De esta forma, cuando Montnegre solicitó audiencia real le respondieron que sin una carta de Felipe V o ser presentado por su embajador no podría ser recibido en calidad de Diputado de Cataluña, sino únicamente a título personal y sin reconocérsele autoridad diplomática, como finalmente sucedió en mayo y sin fortuna para Montnegre. En este intento de defender las leyes catalanas también Pau Ignasi de Dalmases fue recibido por la reina presentando, apoyado por James Stanhope y Peterborough, varias instancias de intercesión en favor de los catalanes, entre ellas una súplica ante las dos Cámaras parlamentarias, pero sus gestiones tampoco tuvieron el resultado deseado (Albareda, 2010, pp. 395-397, 409).

Ante estos movimientos y dada la necesidad de firmar la paz —en pocos días llegaría de Utrecht el tratado firmado con Francia, que debía quedar a disposición del Parlamento junto al preliminar con España- Monteleón aceptó los últimos términos ofrecidos, justificándolo en que así podría pasar a Utrecht con la amistad y el apoyo británico dejando, además a Felipe V la libertad de decidir si los aceptaba o no ${ }^{70}$. Su opinión fue aplaudida en Francia, felicitándole por no alargar la discusión sobre puntos que no merecían semejante atención y criticando al monarca español añadiendo que insistir habría sido hacerle un mal servicio aunque el rey «no pareciese estar convencido de esta verdad ${ }^{71}$.

\section{El cierre de la negociación}

Pese a que todo parecía acabado Monteleón y el Consejo Real aún se reunieron tres veces más. El punto principal era la cuestión religiosa, pero siguieron abordando el caso catalán, jugando Bolingbroke un papel decisivo para vencer las reticencias de la reina sobre la solución acordada al asegurarle que los privilegios castellanos les beneficiarían por ser más prácticos para todo pueblo que quisiera vivir «en la debida sujeción a la autoridad real» (García, 1998, pp. 423-425).

En la primera reunión, celebrada el 28 de abril, tras recordarse lo urgente de la situación pasaron a discutir los dos artículos inconclusos.

AMAE, Correspondance Politique, Angleterre, 244, ff. 227v-228, copia de la carta de Monteleón a Felipe V, 26-IV-1713.

71 AMAE, Correspondance Politique, Angleterre, 244, f. 232, Torcy a Monteleón, 2-V-1713. 
Sobre la cuestión religiosa, Monteleón insistió que era obligación de todo príncipe católico mantener y conservar la religión de sus vasallos, que solo demandaba condiciones básicas para ello y que podrían evitar cualquier inconveniente político, fijando en el acuerdo de paz los términos generales e incluyendo las explicaciones necesarias en un artículo privado y secreto.

Le replicaron que los términos propuestos iban contra las leyes británicas y les expondrían a censura parlamentaria y persecución criminal, siendo impracticable el añadido secreto al tener que presentar al Parlamento la totalidad del acuerdo. Recordaron que Gibraltar y Menorca fueron cedidas sin limitación como territorio conquistado y únicamente negociaban como prueba de amistad, concluyendo que solo estipularían el libre uso de la religión católica en términos generales. Ante la insistencia de Monteleón en incluir al menos alguna cláusula sobre el mantenimiento de la jurisdicción eclesiástica aseguraron que no les concederían más ventajas que a posesiones cedidas sin necesidad de conquista ni entrarían en explicaciones que alterasen la tranquilidad parlamentaria, recordando además que Luis XIV era garante de la entrega incondicional de dichos territorios.

Viendo el cariz de la situación Monteleón pidió tiempo para pensar en lo expuesto y pasaron a la cuestión catalana. Los británicos insistían en que el honor de la reina solo estaría a salvo incluyendo la expresión «privilegios antiguos» pero Monteleón arguyó que los catalanes, proclives a la sedición, lo usarían más adelante para alegar que el rey había faltado a lo prometido. Asimismo, expuso «lo exorbitado de sus privilegios frente a la autoridad real y las desgracias que habían supuesto a España» y cómo eliminarlos, además de permitir el buen gobierno, contribuiría a la independencia de España respecto a Francia «al refrenar a vasallos tan peligrosos», apelando incluso al ejemplo de la unión de Inglaterra con Escocia para defender su postura.

Los ministros británicos apoyaban mayoritariamente sus razones, pero temían que los defensores whigs de la causa catalana causaran problemas de no hacerse referencia expresa a sus privilegios. Al no alcanzar un acuerdo, se decidió que Monteleón y Bolingbroke buscasen una solución que contentase a ambas partes y pusieran en limpio todo el tratado. Tras ello y con las últimas decisiones de la reina sobre los dos puntos en disputa, concluirían el preliminar en una nueva reunión.

Efectivamente, del 28 de abril al 1 de mayo trabajaron juntos redactando un borrador del preliminar que fue leído en el consejo del 1 de mayo, incluyendo sobre la marcha las modificaciones necesarias. En los artículos 1 al 9 y el 12, referido al asiento de negros y ya convenido en Madrid, no existieron problemas.

En el artículo 10 la cesión de Gibraltar se mantuvo sin añadir territorios adyacentes ni consentir comunicación salvo por mar, pero en caso de emergencia o que las condiciones marítimas lo impidiesen se permitiría acceso terrestre con restricciones. No 
consiguió Monteleón prohibir la entrada y resguardo en puerto de las embarcaciones mercantiles moras, pero sí que judíos y moros tuviesen prohibido residir o avecinarse. Por último, debió transigir con tener únicamente opción preferencial para su recompra y que la cuestión religiosa fuera expresada en términos generales.

El artículo 11 acordó la cesión de Menorca en idénticas condiciones salvo dos excepciones. Por el comercio entre británicos y judíos estos podrían residir allí, dándose a cambio permiso a los habitantes de la isla para vender y transportar libremente sus bienes hacia España; y sobre la religión una cláusula especificó que se tomarían los expedientes necesarios para su conservación que no fuesen contrarios al gobierno civil y leyes británicas.

El artículo 13 trataba el espinoso tema de la amnistía y las leyes catalanas. Se le comunicó que era preciso articularlo resguardando el honor real y ello solo podía obtenerse incluyendo la palabra «privilegios». Tras un intenso debate Monteleón consiguió que el artículo expresara que tras realizar la reina todos los esfuerzos para que los catalanes consiguiesen perdón y amnistía general con la conservación de bienes, honores y sus antiguos privilegios, en atención a ella no solo se les concedía el perdón y conservación de bienes y honores sino también todos los privilegios que los pueblos de Castilla gozaban ese momento o tendrían en el futuro.

El último artículo sobre el que se realizó alguna anotación fue el referente a la cesión de Sicilia, donde Monteleón aseguró las haciendas y honores de los súbditos de Felipe V, siendo los restantes formalidades propias de todo tratado que no requirieron modificación.

Quedaban así plasmados los términos definitivos del preliminar de paz, que sería firmado cuando llegase de Utrecht el tratado franco-británico. Quedó para un último consejo acordar conjuntamente las órdenes que remitirían sobre el tratado a los plenipotenciarios en Utrecht.

Monteleón estaba exultante por el resultado final. Había conseguido excluir las leyes catalanas, permitiendo al mismo tiempo a los británicos asegurar que les habían conseguido los privilegios castellanos. A ese respecto, y mientras Bolingbroke afirmaba que se había plasmado de la forma más suave y favorable posible para los españoles de acuerdo con la dignidad y el honor de la reina ${ }^{72}$, Monteleón aseguró «yo mismo no sé cómo he podido reducir a esta gente a esto, y solo la fuerza de la razón del rey y una respetuosa entereza sin que pareciese resistencia a sus empeños lo ha logrado vencer».

Tras ello solo quedó esperar la llegada del tratado franco-británico, y cuando el 12 de mayo el secretario del obispo de Bristol arribó con él Monteleón fue convocado

$72 \quad$ N.A, State Papers 105/270, ff. 107-108, Bolingbroke a Dartmouth, 8-V-1713. 
a su tercer consejo. Celebrado el día 14, se releyó el borrador del preliminar de paz y dos originales fueron firmados por Monteleón y Bolingbroke. El negociador español se quedó con uno para llevarlo a Utrecht, enviando una copia a Madrid.

Posteriormente se leyeron las instrucciones a los plenipotenciarios británicos, instándoles a apoyar las razones españolas frente a los demás aliados y especialmente ante las pretensiones comerciales holandesas y, para satisfacción de Monteleón, a tratarle con toda confianza y ayudarle en cuanto precisara. Incluyeron además los tres artículos separados aprobados por Lexington en Madrid: no permitir más desmembramientos de la monarquía hispánica, la conservación del derecho de investidura de Siena y la concesión de un principado, preferiblemente en Limburgo, a la princesa de los Ursinos. Monteleón especificó a Madrid que se presentaban separados porque veían posible estipular esas condiciones en las paces con las restantes potencias. En ese caso Gran Bretaña quedaría únicamente como garante del acuerdo, pero de no acordarse alguno de ellos se obligaría a efectuar su cumplimiento ${ }^{73}$.

Dos días después se publicó la paz entre Inglaterra y Francia y el 19 se presentó al Parlamento el tratado y ratificación de la paz concluida y el tratado preliminar con España, asegurando que sería firmado en Utrecht a la mayor brevedad (Cobbet, 1810, Vol.VI, pp. 1208-1210).

Monteleón quedó muy satisfecho de su actuación y consiguió el cariño de los británicos que le definieron como «un ministro que se ha hecho igualmente querer y estimar», lamentando Bolingbroke «perder al mismo tiempo el placer de tratar con un ministro hábil y convivir con un amigo agradable» ${ }^{74}$. También en Francia se mostraron encantados, afirmando que había sido el negociador ideal, puesto que cualquier otro habría retrasado enormemente la negociación ${ }^{75}$.

Su único lunar fue el fracaso en añadir las cláusulas sobre la religión, pero lo consideró la única alternativa a la sumisión por derecho de conquista ${ }^{76}$. Si temía que en Madrid no aprobasen ese artículo y el problema que supondría pretender modificar un texto ya presentado al Parlamento británico, fue un miedo infundado. El 15 de mayo se informó a Lexington que Felipe V aceptaba lo ejecutado por Monteleón sobre asuntos de religión y la cuestión catalana ${ }^{77}$ y el 5 de junio de su aprobación sin modificaciones del tratado preliminar $^{78}$.

\footnotetext{
73 AMAE, Correspondance Politique Angleterre, 245, ff. 87-97, copia de la carta de Monteleón a Grimaldo, 22-V-1713.

74 Parke, 1798, vol. 4, pp. 91-92, Bolingbroke a Ursinos, 8/19-V-1713.

$75 \quad$ Ibidem, pp. 146-147, Torcy a Bolingbroke, 21-V-1713.

76 AMAE, Correspondance Politique Angleterre, 245, f. 96, copia de la carta de Monteleón a Grimaldo, 22-V-1713.

77 B.L. Additional Manuscripts, 46550, ff. 88-89, Grimaldo a Lexington, 15-V-1713.

78 Ibidem, ff. 96-97, Grimaldo a Lexington, 5-VI-1713.
} 
Pero para ese momento Monteleón ya no estaba en Londres. Finalizada su misión, en los últimos días de mayo pasó a Utrecht en una embarcación de la reina para rematar la paz junto al duque de Osuna ${ }^{79}$. Los británicos le esperaban con ansia, ya que Osuna pretendía incluir modificaciones por creer que el apoyo dado a Baviera era excesivo y oponerse especialmente a ceder Sicilia y conceder el navío de permiso a los británicos (Albareda, 2015, pp. 88-89). Pese a ser este el plenipotenciario principal Monteleón trató de llevar en solitario las restantes negociaciones diciéndole que tenía instrucciones detalladas de Felipe V sobre cómo realizarlas, pero negándose a enseñárselas. Aquello marcó el inicio de una relación nefasta entre ambos, llegando Osuna a solicitar que se le excusara de firmar el tratado - cosa que finalmente no sucedió- y siendo tan habituales sus discusiones incluso ante diplomáticos de otras potencias que tuvieron que ser llamados al orden por el monarca (Fernández, 2011, pp. 128-130). Pese a todo Utrecht fue un congreso de alcance limitado y que, prácticamente constreñido a ratificar previamente negociado entre Francia y Gran Bretaña, no vivió grandes cambios ni negociaciones clave. No extraña por tanto que pese a aparecer algunos puntos de fricción - especialmente los intentos Felipe $\mathrm{V}$ de ser reconocido como soberano de los territorios que iba a ceder en el preámbulo del tratado e incluir en el tratado principal lo referente al principado de la princesa de los Ursinos y la tentativa británica de resolver algunas peticiones portuguesas - la paz entre ambas potencias acabara firmándose el día 13 de julio de 1713 en términos casi idénticos y sin ningún cambio sustancial a lo acordado en Londres.

\section{Conclusión}

El estudio de esta negociación — junto a la de Lexington en Madrid — presenta gran importancia permitiéndonos comprobar las prioridades de Felipe $\mathrm{V}$ respecto a su diplomacia de paz, la concepción —al menos inicial— de la capacidad internacional de su monarquía y revelando una mayor independencia respecto a Francia de lo que se presuponía.

El caso de Monteleón es especialmente relevante por ser la primera vez que uno de sus negociadores pudo interactuar directamente con diplomáticos enemigos con capacidad de decisión. Las instrucciones y respuestas que recibió nos permiten comprobar una dualidad en Felipe V. Superadas sus primeras instrucciones, acertadamente definidas como maximalistas e incluso ingenuas por Albareda (2010, p. 321), presenta una serie de intereses consistentes con lo que realmente podía aspirar, buscando mantener posiciones en Italia y minimizar pérdidas territoriales. Extraña sin embargo

79 Parke, 1798, vol. 4, p. 91, Bolingbroke a Ursinos, 8/19-V-1713. 
que no hubiera un mayor empeño ni estrategia para recuperar Gibraltar y Menorca, que a priori debería haber sido uno de los principales objetivos en Londres, y resulta más llamativo aún al comprobar la insistencia por asegurar el catolicismo en ambos emplazamientos por mucho que ello pueda justificarse en la profunda religiosidad del monarca y su lógica preocupación por garantizar la religión en territorios cedidos. Igualmente, llamativa es la fijación, rayana con la obsesión, por otros temas que, sobre el papel, deberían ser secundarios o negociables y que devinieron en principales caballos de batalla eclipsando y debilitando asuntos de mayor enjundia para el futuro de la monarquía hispánica. La rigidez vista en el caso catalán, donde la lógica aconsejaba buscar un término medio y no convertirlo en condición irrenunciable y su fijación por conseguir el principado para la princesa de los Ursinos, llegando a amenazar la paz -Felipe V bloqueó incluso durante un tiempo la conclusión del tratado con Holanda, buscando asegurar la concesión del principado - nos muestran la contraparte de un monarca que debió ser fuertemente presionado para dejar de anteponer estos temas a las necesidades políticas más primordiales.

En cuanto a Monteleón, aunque los acuerdos franco-británicos sobre la monarquía hispánica limitaron su actuación y se vio duramente presionado, pudo hacerse fuerte en ciertos aspectos y gozar de cierta capacidad de maniobra.

Jugó en su favor la necesidad tory de cerrar el acuerdo lo antes posible. Las contradicciones internas del gobierno, el posible vuelco político y —más aún— las consecuencias que podría tener que el Parlamento comprobase que el primer anuncio de la conclusión del preliminar era falso, les forzó a una mayor receptividad para conseguir finalizar el acuerdo lo antes posible. Además, tenían puesto su objetivo en obtener ciertas ventajas comerciales y asegurarlas influyó en que, salvo ciertas líneas rojas infranqueables como el tema religioso, adoptasen una mayor elasticidad respecto a otras cuestiones. Puede decirse que, al contrario que Felipe V, supieron anteponer el pragmatismo político a la consecución de objetivos secundarios y al propio cumplimiento de los compromisos adquiridos con sus aliados. Esto permitió a Monteleón insistir con más fuerza en sus principales objetivos y combinar el rigor cumpliendo su cometido con su evidente deseo de agradar a sus interlocutores. En ese sentido, su deseo de ocupar la embajada en Londres tras la paz ayuda a entender los riesgos asumidos al contravenir órdenes directas y su afán en forjar buenas relaciones con las principales personalidades británicas.

Alejada de la oficialidad de Utrecht, Londres resultó el foco decisivo a la hora de concretar la paz hispano-británica, modificando incluso aspectos acordados en Madrid, y además de mostrar las principales preocupaciones y fijaciones de Felipe $\mathrm{V}$, también dejó ver algunas de sus principales aspiraciones, esencialmente en lo referido a Italia, y que marcarían la política exterior del Borbón en el escenario europeo abierto tras la paz. 


\section{AGRADECIMIENTOS}

Este artículo se inscribe dentro de la investigación del proyecto del Ministerio de Ciencia, Innovación y Universidades: España y Francia (PGC2018-097737-B-I00): Intereses dinásticos e intereses nacionales (1701-1733) y del Grup d'estudi de les institucions $i$ de les cultures politiques (segles XVI-XXI) (2017 SGR 1041). 


\section{Bibliografía}

Albareda Salvadó, Joaquim (2000), La guerra de successió i l'onze de setembre, Barcelona, Empuries.

Albareda Salvadó, Joaquim (2010), La Guerra de Sucesión de España: (1700-1714), Barcelona, Crítica.

Albareda Salvadó, Joaquim (2013), «Felipe y la negociación de los tratados de Utrecht: bajo los dictados del 'mejor abuelo del mundo'», Cuadernos de Historia Moderna, Anejos, XII, pp. 31-60<https://doi.org/10.5209/rev_CHMO.2013.43279>.

Albareda Salvadó, Joaquim (2015), «Los tratados de Utrecht-Rastatt y España: ceder lo mínimo para conservar lo principal», en Albareda Salvadó, J. (ed.), El declive de la monarquía y del imperio español: los tratados de Utrecht, (1713-1714), Barcelona, Crítica, pp. 65-122.

Albertí, Santiago (1964), L'onze de setembre, Barcelona, Albertí Editor S.L.

Baudrillart, Alfred (1890), Philippe V et la cour de France, Paris, Librairie de Fermin-Didot, vol 1.

BÉLY, Lucien (1990), Espions et ambassadeurs au temps de Louis XIV, París, Fayard.

BÉLY, Lucien (2011), «Peut-on parler d'une opinion publique internationale à l'époque moderne? », en Bély, L. (ed.), L'opinion publique en Europe (1600-1800), Paris, Presses de l'Universite Paris-Sorbonne, pp. 161-181.

Castellano García, Manuel (2016), «François Gaultier, un artisan de la paix d'Utrecht, (1711-1713)», Revue d'Histoire Diplomatique, 3, pp. 257-275.

Castellví I Obando, Francesc (1997-2002). Narraciones históricas, en Mundet, J. M. y Alsina, J. (eds.), Madrid, Fundación Francisco Elías de Tejada y Erasmo Pércopo, vol 3.

Coвbett, William (1810), The Parliamentary History of England from the Earliest Period to the Year 1803, London, T. C. Hansard, vol. 6.

Dickinson, Harry (1970a), Bolingbroke, London, Constable.

Dickinson, Harry (1970b), «The October Club», Huntington Library Quarterly, 33, 2, pp. 155-173. <https://doi.org/10.2307/3816719>.

Fernández Durán, Reyes (2011), La Corona española y el tráfico de negros: del monopolio al libre comercio, Madrid, Ecobook.

GARCÍA CÁRCEL, Ricardo (1998), «La opinión catalana sobre Francia en la primera mitad del siglo XVIII», Pedralbes: revista d'història moderna, 18, 2, pp. 421-437.

GregG, Edward (1980), Queen Anne, London, Routhledge.

GUERRERo ViLlar, Joaquín (2008). El tratado de paz con Inglaterra de 1713. Orígenes y culminación del desmembramiento de la monarquia española, Tesis doctoral inédita, Universidad Autónoma de Madrid. 
GuILlamón Álvarez Francisco Javier y MuÑoz Rodríguez, Juan (2008), Educando al príncipe: correspondencia privada de Luis XIV a Felipe V durante la Guerra de Sucesión, Rosario, Prohistoria.

HiLl, Brian (1988), Robert Harley, Speaker, Secretary of State and Premier Minister, London, Yale University Press.

Holmes, Geoffrey (1969), British politics in the Age of Anne, Nueva York, Mc.Millan.

LEÓn SANZ, Virginia (2013), «De La Haya a Utrecht. Las negociaciones de paz en la Corte de Barcelona (1709-1714)», en Dantí, J., Gil, X. y Mauro, I. (coords.), Actes del VIII Congrés d'Història Moderna de Catalunya: "Catalunya, entre la guerra i la pau, 1713, 1813”: Comunicacions, Barcelona, Universitat de Barcelona, vol. 1, pp. 93-123.

LóPEZ-Cordón CoRTEzo, María Victoria (2020), «Entre política y sociabilidad, o de como la Conferencia de Utrecht fue mucho más que unos tratados», en Gómez Mezquita, Ma. L. (ed.), Sociedad, cultura y política en el Antiguo Régimen: Prácticas y representaciones en la monarquía española, Buenos Aires, Biblos [Ed. Ebook], pp. 128-171.

Muñoz GonzÁlez, Antoni y CATÀ I TuR, Josep (2009), La traïció anglesa: comerç colonial i destrucció de la sobirania catalana, 1706-1715, Barcelona, Llibres de l'Index.

PARKe, Gilbert [ed.] (1798), Letters and correspondance, public and private, of the Right Honourable Henry St. John, Lord viscount Bolingbroke, London, G. G. \& J Robinson, vols. 2, 3, 4.

SANPERE I MiQuel, Salvador (1905), Fin de la nación catalana, Barcelona, Tipografia l’Avenç. [Ed. Facsimil, 2001. Barcelona, Base].

STORrs, Christopher (2013), «How war ends: Lord Lexington's mission to Madrid 1712-1713», Cuadernos de Historia Moderna, Anejos, 12, pp. 77-99. < https://doi. org/10.5209/rev_CHMO.2013.43281>.

SzECHI, Daniel (1984), Jacobitism and Tory politics, 1710-14, Edimburgo, John Donald Publishers.

Trevelyan, George Macaulay (1934), England under Queen Anne, London, Longsman \& Greene, vol. 8 .

VIDAL, Josep Juan (2014), «El austracismo en el reino de Mallorca», Cuadernos dieciochistas, 15, pp. 165-193. < https://doi.org/10.14201/cuadieci201415165193>. 
